\title{
Herring Investigations at Plymouth. V. The Plymouth Winter Fishery during the Season 1927-28.
}

\author{
By
}

\author{
E. Ford, A.R.C.Sc., \\ Naturalist at the Plymouth Laboratory.
}

With 7 Figures in the Text.

\section{CONTENTS}

The Winter Fishery of 1927-28.

The Steam Fishery .

The Motor Fishery .

Value of the Fishery

The Characters of the Fishes Landed

Average Length

Age Composition of Samples

The Year-class 1920

Length for Age

Predictions of Future Fisheries

Age Composition during the four Seasons 1924-25 to 1927-28 .

Age Composition in Relation to Density of Landings . . . . . . . . 17

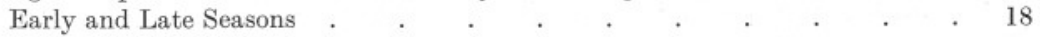

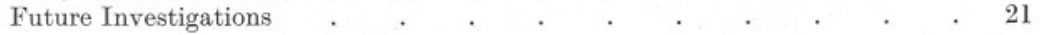

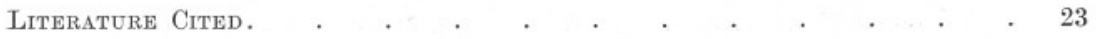

Tables. . . . . . . . . . . . . . . . . . 23

DURING the winter of 1927-28 the progress of the herring fishing at Plymouth was followed for the fourth consecutive season. A diary of market events was again kept by Mr. A. J. Smith of the Laboratory staff, while statistics of commercial landings and of the number of visiting drifters were kindly supplied by Mr. T. Edser of the Statistical Department, Ministry of Agriculture and Fisheries, and by Mr. E. C. Nelder of the Sutton Harbour Improvement Company, respectively. In the examination of age and growth of random samples of herrings, Mr. F. J. Warren, Laboratory Assistant, again acted as recorder. Details of the methods of treatment of the data collected will be found in Part I of this series of Reports (Ford, 1).

\section{The Winter Fishery of 1927-28.}

The season was in several ways a notable one. It will be seen from the following table that in spite of a marked reduction in the number of 
E. FORD.

boats fishing, particularly in the case of steamers, the total quantity of herrings landed created a record :-

$\begin{array}{cccccc}\begin{array}{c}\text { Season } \\ \text { Dec.-Jan. }\end{array} & \begin{array}{c}\text { Number of } \\ \text { East } \\ \text { Country } \\ \text { steamers. }\end{array} & \begin{array}{c}\text { Number of } \\ \text { West Country } \\ \text { (Cornish) } \\ \text { motor drifters* }\end{array} & \begin{array}{c}\text { Total Quantity } \\ \text { of }\end{array} & \begin{array}{c}\text { Quantity landed } \\ \text { by } \\ \text { cwt. }\end{array} & \begin{array}{c}\text { Quantity landed } \\ \text { by motor }\end{array} \\ 1918-19 & 33 & 139 & 8,624 & \begin{array}{c}\text { steamers only. } \\ \text { cwt. }\end{array} & \begin{array}{c}\text { drifters } \dagger \text { only. } \\ \text { cwt. }\end{array} \\ 1919-20 & 30 & 156 & 29,425 & 7,628 & 996 \\ 1920-21 & 26 & 182 & 40,263 & 12,728 & 16,697 \\ 1921-22 & 31 & 155 & 16,922 & 10,973 & 19,290 \\ 1922-23 & 68 & 142 & 54,839 & 40,994 & 6,428 \\ 1923-24 & 59 & 161 & 98,684 & 57,519 & 13,898 \\ 1924-25 & 86 & 176 & 113,585 & 83,647 & 29,165 \\ 1925-26 & 153 & 158 & 105,643 & 82,780 & 22,938 \\ 1926-27 & 129 & 169 & 63,138 & 45,932 & 17,206 \\ 1927-28 & 77 & 145 & 122,419 & 82,803 & 39,616\end{array}$

\section{The Steam Fishery.}

There has been an appreciable decline in the number of steamers visiting Plymouth during the past two seasons, due, probably, to the fact that the fishery had experienced several indifferent seasons in succession. In the months of December, 1927, and January, 1928, however, the seventy-seven steamers made a total of 1789 landings of an average weight of $46 \cdot 6 \mathrm{cwt}$. This result was a welcome improvement on the averages for the corresponding months of the seasons 1925-26 and 1926-27 (23.1 cwt. and 16.6 cwt. respectively), as well as on the average of $26.6 \mathrm{cwt}$., covering the longer period of nine seasons from December, 1918, to January, 1927.

Whether or no the steamers, by ceasing fishing towards the end of January, leave the district when fishing might yet prove profitable, is a question worthy of investigation. The work of the past few years has created the impression that to the westward of Plymouth there may be an assemblage of well-grown, comparatively later-spawning herrings which are not every year fully exploited. Some of the small local drifters, when weather permits, certainly continue to make catches until well on into March, while the study of fishes landed during February and March has shown that an appreciable proportion of them have yet to spawn. Wallace (4, p. 35), too, has shown that later spawning of considerable intensity does occur in westerly waters in the neighbourhood of Gribbon Head. In such a season as the one now under review, when consistently good catches to the eastward are made, there is a decided tendency to bring the fishery to a close as soon as the easterly shoals show signs of exhaustion. In consequence of this, the late westerly fish are liable to be almost entirely neglected.

\footnotetext{
* A small number of Plymouth motor drifters take part in the fishery, numbering on average about twelve.

$\dagger$ These figures are inclusive of the landings by Plymouth boats.
} 


\section{The Motor Fishery.}

The total weight of fish landed by the motor drifters during December, 1927, and January, 1928, was the heaviest since the record season of 1923-24. This satisfactory aggregate, however, in contrast with that of the steamers, was chiefly due to a considerable rise in the total number of landings made, rather than to an increase in the average weight per individual landing. Thus, although the total number of landings was the greatest recorded since the Ministry's more modern system of statistics was adopted in 1906, the average weight of $24 \cdot 6 \mathrm{cwt}$. per landing did not greatly exceed the average of $22 \cdot 6 \mathrm{cwt}$. for the nine-year period from December, 1918, to January, 1927.

As in past seasons, a considerable weight of fish was landed by the steamers on days when the motor drifters made no landings. Thus, on 22 days (inclusive of 6 Sundays) during December, 1927, and January, 1928 , a total of 29,708 cwt. was landed by steamers, while there were no landings at all by motors.

\section{Value of the Fishery.}

The total value of the fishery during each of the past twenty-two seasons is shown in the following table, together with the average price per 1 cwt. :-

$\begin{array}{cr}\begin{array}{c}\text { Season } \\ \text { (Dec.-Jan.) }\end{array} & \begin{array}{c}\text { Total Weight } \\ \text { landed. } \\ \text { (cwt.) }\end{array} \\ 1906-07 & 32,913 \\ 1907-08 & 23,957 \\ 1908-09 & 4,257 \\ 1909-10 & 52,544 \\ 1910-11 & 37,741 \\ 1911-12 & 39,167 \\ 1912-13 & 8,171 \\ 1913-14 & 28,886 \\ 1914-15 & 7,585 \\ 1915-16 & 11,582 \\ 1916-17 & 24,293 \\ 1917-18 & 38,108 \\ 1918-19 & 8,624 \\ 1919-20 & 29,425 \\ 1920-21 & 40,263 \\ 1921-22 & 16,922 \\ 1922-23 & 54,839 \\ 1923-24 & 98,684 \\ 1924-25 & 113,585 \\ 1925-26 & 105,643 \\ 1926-27 & 63,138 \\ 1927-28 & 122,419\end{array}$

Total Value.
$£$
8,040
6,583
2,521
16,105
17,048
18,158
3,594
13,933
6,021
13,062
35,901
88,453
15,160
40,045
42,752
14,792
26,326
65,290
109,294
89,334
47,539
65,451

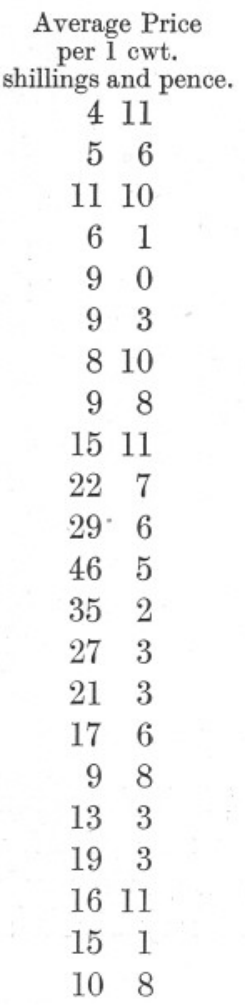


E. FORD.

It will be seen that during the season 1927-28, although a record total weight of fish was landed, the average price per $1 \mathrm{cwt}$. was, with the solitary exception of the season 1922-23, easily the lowest realised since the pre-war season of 1913-14. Thus, it is only necessary to refer back to the season 1925-26 to discover a total financial yield exceeding that of 1927-28.

It is of some local interest to note that the seasonal average price per 1 cwt. realised at Plymouth has almost always been greater than the yearly average price of herrings of British taking generally. This fact is brought out in the following table and in Fig. 1 :-

\begin{tabular}{|c|c|c|c|c|c|}
\hline Year. & \multicolumn{2}{|c|}{$\begin{array}{c}\text { Herrings. } \\
\text { British Taking. } \\
\text { Average Price per } 1 \text { cwt. }\end{array}$} & $\begin{array}{r}\text { Herr } \\
\text { Plymout } \\
\text { Average Pric } \\
\text { shillings. }\end{array}$ & $\begin{array}{l}\text { ags. } \\
\text { only. } \\
\text { per } 1 \text { cwt. } \\
\text { pence. }\end{array}$ & $\begin{array}{c}\text { Season } \\
\text { Dec.-Jan. }\end{array}$ \\
\hline 1906 & 8 & 1 & & & $1906-07$ \\
\hline 1907 & 5 & 1 & $\begin{array}{l}4 \\
5\end{array}$ & $\begin{array}{r}11 \\
6\end{array}$ & $1907-08$ \\
\hline 1908 & 5 & 7 & $\stackrel{5}{1}$ & 0 & 1000 \\
\hline 1909 & 6 & 0 & 11 & 10 & 1908-09 \\
\hline 1910 & 7 & 8 & 6 & 1 & $1909-10$ \\
\hline 1911 & 5 & 11 & 9 & 0 & 1910-11 \\
\hline 1912 & 6 & 2 & 9 & 3 & 1911-12 \\
\hline 1913 & 6 & 4 & 8 & 10 & $1912-13$ \\
\hline 1914 & 6 & 9 & 9 & 8 & 1913-14 \\
\hline 1915 & 16 & 5 & 15 & 11 & 1914-15 \\
\hline 1916 & 21 & 11 & 22 & 7 & 1915-16 \\
\hline 1917 & 22 & 10 & 29 & 6 & 1916-17 \\
\hline 1918 & 24 & 6 & 46 & 5 & $1917-18$ \\
\hline 1919 & 14 & 1 & 35 & 2 & 1918-19 \\
\hline 1920 & 11 & 11 & 27 & 3 & 1919-20 \\
\hline 1921 & 4 & 7 & 21 & 3 & $1920-21$ \\
\hline 1922 & 7 & 1 & 17 & 6 & $1921-22$ \\
\hline 1923 & 7 & 11 & 9 & 8 & $1922-23$ \\
\hline 1924 & 11 & 4 & 13 & 3 & 1923-24 \\
\hline 1925 & 10 & 5 & 19 & 3 & 1924-25 \\
\hline 1926 & 8 & 7 & 16 & 11 & $1925-26$ \\
\hline 1927 & 9 & 5 & 15 & 1 & $1926-27$ \\
\hline & & & 10 & 8 & $1927-28$ \\
\hline
\end{tabular}

The daily returns of landings and market prices at Plymouth during December, 1927, provide a good illustration of the fact that the ruling price on the market is to a greater or lesser extent dependent upon the quantity of fish available. In the following table, daily landings have 


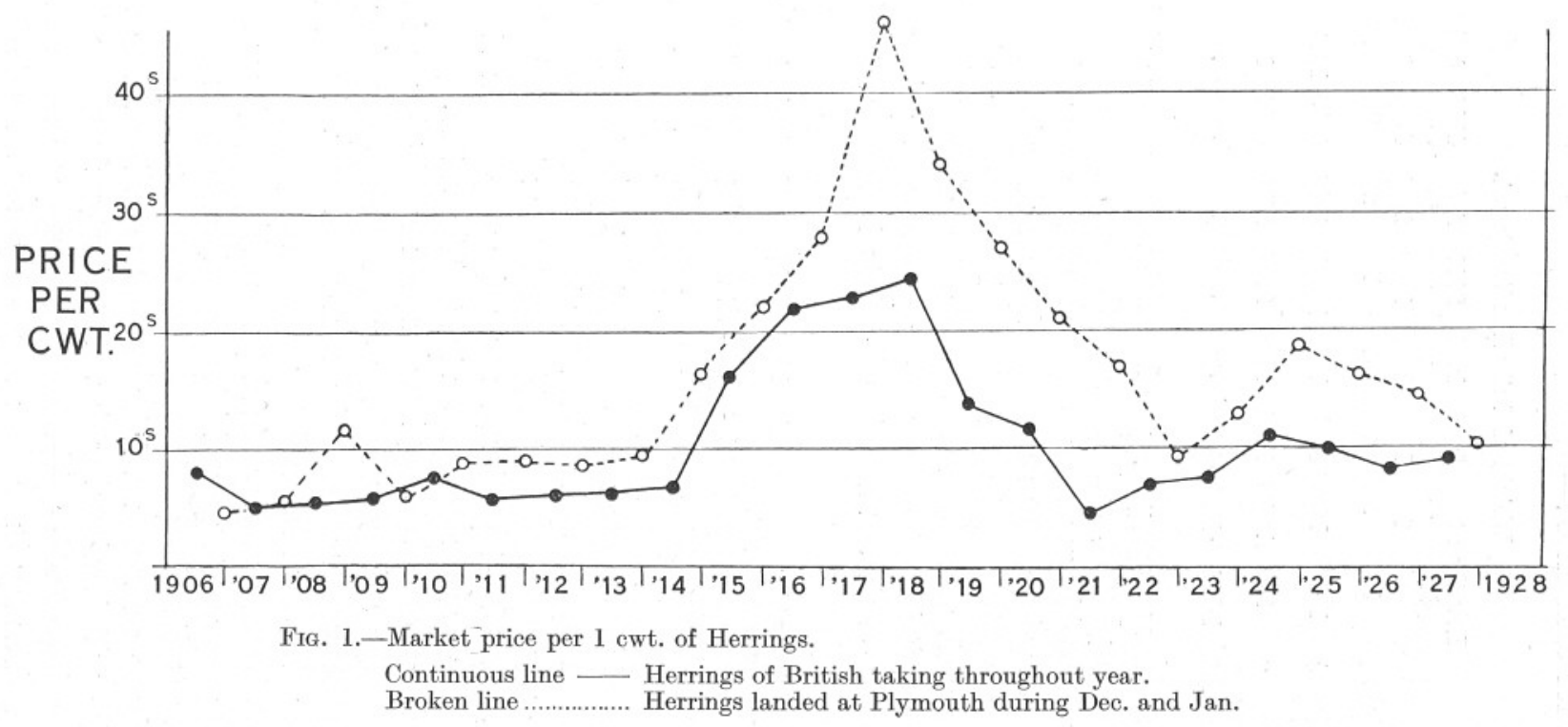


been grouped into convenient classes and the average price per $1 \mathrm{cwt}$. calculated for each class :-

Weight of Daily Landing (cwt.).

\begin{tabular}{|c|c|c|c|c|c|c|c|c|c|c|}
\hline & $\begin{array}{c}\text { Less than } \\
500\end{array}$ & $\begin{array}{c}500 \\
\text { to } \\
999\end{array}$ & $\begin{array}{l}1000 \\
\text { to } \\
1499\end{array}$ & $\begin{array}{c}1500 \\
\text { to } \\
1999\end{array}$ & $\begin{array}{l}2000 \\
\text { to } \\
2499\end{array}$ & $\begin{array}{l}2500 \\
\text { to } \\
2999\end{array}$ & $\begin{array}{c}4000 \\
\text { to } \\
4499\end{array}$ & $\begin{array}{c}5000 \\
\text { to } \\
5499\end{array}$ & $\begin{array}{c}5500 \\
\text { to } \\
5999\end{array}$ & $\begin{array}{c}7000 \\
\text { to } \\
7499\end{array}$ \\
\hline $\begin{array}{l}\text { No. of Days } \\
\text { otal weight }\end{array}$ & 5 & 2 & 3 & 4 & 7 & 2 & 2 & 3 & 1 & 1 \\
\hline $\begin{array}{l}\text { landed (cwt.) } \\
\text { Average weight }\end{array}$ & 1336 & 1409 & 3581 & 7140 & 15311 & 5750 & 8600 & 15818 & 5650 & 701 \\
\hline $\begin{array}{l}\text { (cwt.) per day } \\
\text { verage price per }\end{array}$ & 267 & $704 \cdot 5$ & 1194 & 1785 & 2187 & 2875 & 4300 & 5273 & 5650 & 701 \\
\hline 1 cwt. (£) & $1 \cdot 186$ & $\cdot 9645$ & $\cdot 6782$ & $\cdot 596$ & $\cdot 566$ & $\cdot 433$ & $\cdot 483$ & $\cdot 367$ & $\cdot 256$ & $\cdot 32$ \\
\hline
\end{tabular}

In Fig. 2 the average price per $1 \mathrm{cwt}$. for the average weight in each class has been plotted, and the smooth curve $A B$ drawn freehand to provide a reasonably good representation of the general downward trend of the average price as the size of the daily landing increases. It is seen that this curve falls steeply at first, but less and less rapidly later. By erecting perpendiculars from the correct points along the base line, to cut the curve $A B$, it is possible to read off the average price per $1 \mathrm{cwt}$. for landings of given size. The following data have been obtained in this manner :-

$\begin{array}{rrrrrrrrr}\begin{array}{l}\text { Weight of landing (cwt.) } \\ \text { Approx. average price per l cwt. } \\ \text { (shillings and pence) }\end{array} & 500 & 1000 & 2000 & 3000 & 4000 & 5000 & 6000 & 7000 \\ \begin{array}{r}\text { Approx. average price per llb. } \\ \text { (pence) }\end{array} & 2 \cdot 1 & 15 /- & 11 / 6 & 9 / 11 & 8 / 6 & 7 / 4 & 6 / 3 & 5 / 4 \\ & 1 \cdot 6 & 1 \cdot 1 & \cdot 9 & \cdot 8 & \cdot 7 & \cdot 6\end{array}$

It is also of interest to note that during December, 1927, on 15 out of the total of 30 days on which fish were actually landed, a total of 48,085 cwt., representing about $67 \%$ of the total weight landed throughout the month, was sold at a daily average price varying from 10 s. to $5 \mathrm{~s}$. per 1 cwt. ; that is, at the rate of from $1 d$. to $\frac{1}{2} \mathrm{~d}$. per $1 \mathrm{lb}$.

In applying these statistics, however, it must be borne in mind that they are averages; they smooth over those differences in price, often appreciable, between different sales on the same day. Every prospective buyer knows his own immediate requirements, and bids accordingly. One needs a given quantity of fish of the finest quality procurable for which he is prepared to pay a high price. Having secured these fish, he is indifferent to all subsequent sales. On the other hand, a second buyer is not likely to compete for fish until the price has fallen to a certain figure, but he will then buy heavily. The average figures for the day used in the foregoing considerations thus represent the mean of individual sale prices which may differ to a marked degree, so that in drawing comparisons such as that between prices at the source and those paid by the consumer these averages must be applied with great caution, if at all. 
So far as actual fishing and marketing operations are concerned, however, they are instructive. By utilising the data derived from the curve AB on Fig. 2 we can determine the approximate total market value of a day's catch of given weight; thus :-

\begin{tabular}{|c|c|c|c|c|c|c|c|c|}
\hline Weight of landing (cwt.) & 500 & 1000 & 2000 & 3000 & 4000 & 5000 & 6000 & 7000 \\
\hline $\begin{array}{l}\text { Approx. average price per } 1 \mathrm{cwt} \text {. } \\
\text { (shillings and pence) }\end{array}$ & $20 /-$ & $15 /-$ & $11 / 6$ & $9 / 11$ & $8 / 6$ & $7 / 4$ & $6 / 3$ & \\
\hline Approx. total value of landing $(\mathfrak{E})$ & 500 & 750 & 1150 & 1485 & 1700 & 1835 & 1875 & 18 \\
\hline
\end{tabular}

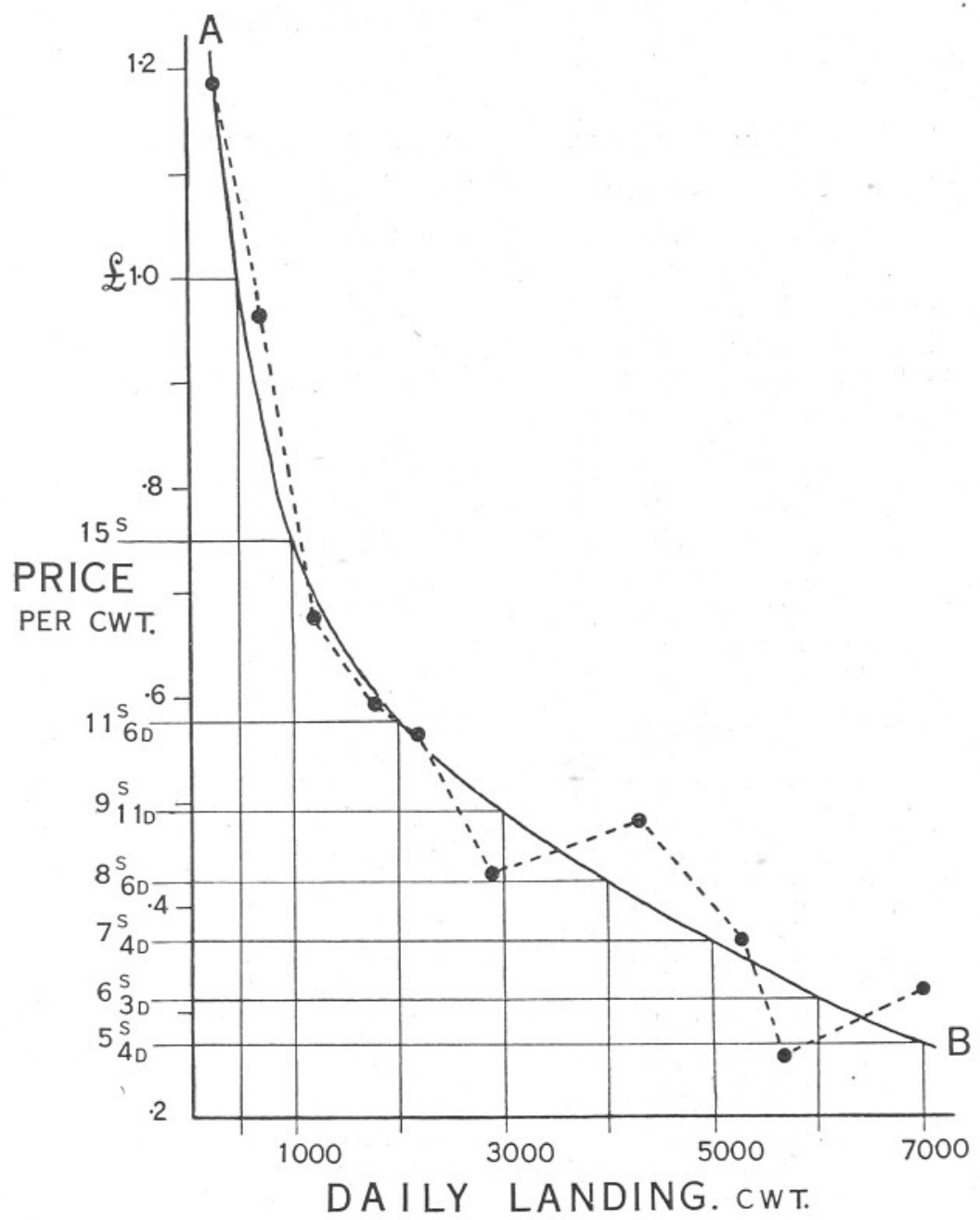

FIG. 2.-Market price per 1 cwt. of Herrings landed by steamers during Dec., 1927.

The continuous curve $\mathrm{AB}$ is drawn freehand as an approximate fit to the observed values, and from it the price per 1 cwt. for a daily landing of given size may be estimated. 
To the mind of the fisherman these figures mean that during December, 1927, in increasing the total weight of fish landed in a day from 1000 cwt. to 2000 cwt., he received $£ 400$ for the additional 1000 cwt., whereas in raising the daily total from $4000 \mathrm{cwt}$. to $5000 \mathrm{cwt}$., the remuneration he received for the additional 1000 cwt. had dwindled to $£ 135$. And what is more, any amount of fish in excess of $5000 \mathrm{cwt}$. per day was literally given away.

These figures also suggest that during this period buyers were not prepared to spend much more than $£ 1800-£ 1900$ on daily catches aggregating 5000 cwt. or over.

\section{The Characters of the Fishes Landed.}

Eleven samples from commercial landings between October 17th, 1927, and March 3rd, 1928, were examined for length, sexual condition, age, and growth. The possession of corresponding data for the three preceding seasons undoubtedly adds to the interest and value of the present records, enabling useful comparisons to be made from which a more intelligent view of events frcm year to year can be obtained.

\section{Average Length.}

In Table I on page 23 the values of the median length $\left(Q_{2}\right)$, the quartiles $\left(Q_{1}\right.$ and $\left.Q_{3}\right)$, and the upper and lower limits of size for each sample are given. Corresponding data for previous seasons were given in Part III (Ford, 2, p. 301). The means of the individual values of $Q_{1}$, $Q_{2}$, and $Q_{3}$ for each season provide a rough indication of the length distribution, and in the following table these means for the period November to January during the four consecutive seasons are shown :-

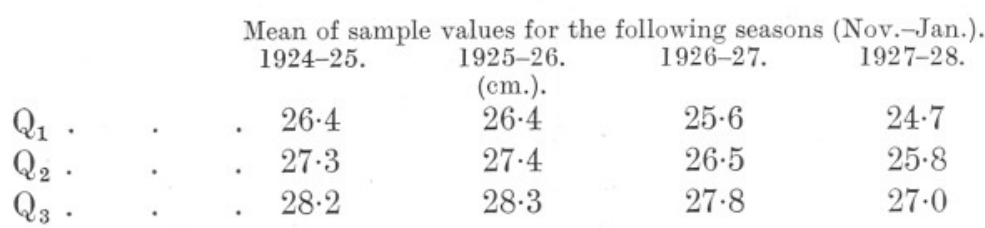

It is seen that the appreciable depression of length during 1926-27 was followed by a further drop during 1927-28. It is true that considerable differences in average size can be occasioned by changes in the size of mesh in the drift-nets used (vide Hodgson, 3), but in the present instance this is not thought to be the important factor. The account of the agecomposition of the samples, given later, will demonstrate convincingly that the 1927-28 samples included a very much larger percentage of young fishes than those of 1925-26 or even 1924-25. Further discussion of the length data will be found on page 12 in conjunction with those on age. 


\section{Age Composition of Samples.}

The age composition of the 1927-28 samples is given in the form of percentages in Table II on page 24. These results are also shown graphically in Fig. 4 on page 11, while, for convenience, the corresponding results for previous seasons have been republished in Fig. 3. It will be noticed that the principle used during the seasons 1924-25 and 1925-26, namely, of including all fishes definitely older than " 6 zones 6 rings " in a composite year-group, has been reverted to. Where interest is chiefly centred on the percentages of well-represented year-classes which either form the mainstay of a current fishery or will become increasingly important in the near future, it is hardly necessary to estimate precisely the age of a few older fishes.

By determining the mean of the individual sample percentages of each year-group, we can arrive at an average composition which will serve as a working summary for the season. Admittedly, such a summary is an approximation, but it facilitates the comparison of results from season to season; it is not intended to stand as an accurate assessment of the age-stock on the grounds. The summary for 1927-28 is as follows :-

Season

(Nov.-

Jan.).

$1927-8$

\begin{tabular}{cccccccccc} 
& \multicolumn{1}{c}{ Percentage Composition by Age. } & \multicolumn{3}{c}{$\begin{array}{c}\text { Older } \\
\text { than }\end{array}$} \\
$2-3$ & 3 & $3-4$ & 4 & $4-5$ & 5 & $5-6$ & 6 & $6-$ old & 6 \\
- & $16 \cdot 5$ & $0 \cdot 2$ & $19 \cdot 2$ & $1 \cdot 2$ & $30 \cdot 4$ & $1 \cdot 8$ & $11 \cdot 1$ & $1 \cdot 1$ & $18 \cdot 2$
\end{tabular}

As an alternative, sample age-data may also be summarised as percentages of definite year-classes, thus :-

\begin{tabular}{|c|c|c|c|c|c|}
\hline $\begin{array}{c}\text { Season } \\
\text { (Nov_Jan.). }\end{array}$ & & Percent & Year & & \\
\hline $1927-28$ & $16 \cdot 5$ & $19 \cdot 2$ & $30 \cdot 4$ & $11 \cdot 1$ & $18 \cdot 2$ \\
\hline
\end{tabular}

It is seen that the 1923 year-class, now as 5-zoned 5-ringed fishes, definitely dominated with a percentage of $30 \cdot 4$. This is in accordance with the expectation expressed in Part III (Ford 2, p. 291) when the previous season's results were under review. Two other facts should be noted at this stage. In the first place, there was an unusually high percentage of 3-zoned 3-ringed fishes (1925 year-class), the significance of which will be dealt with later. Secondly, the year-class 1920, so dominant a constituent of the samples from the landings of the three previous seasons, no longer formed an important element.

\section{The Year-class 1920.}

It has previously been shown that fishes of the year-class 1920 were much in evidence during the seasons 1924-25, 1925-26, and 1926-27 (Ford, 2, p. 289). As 5-zoned 5-ringed fishes in 1924-25 they comprised 


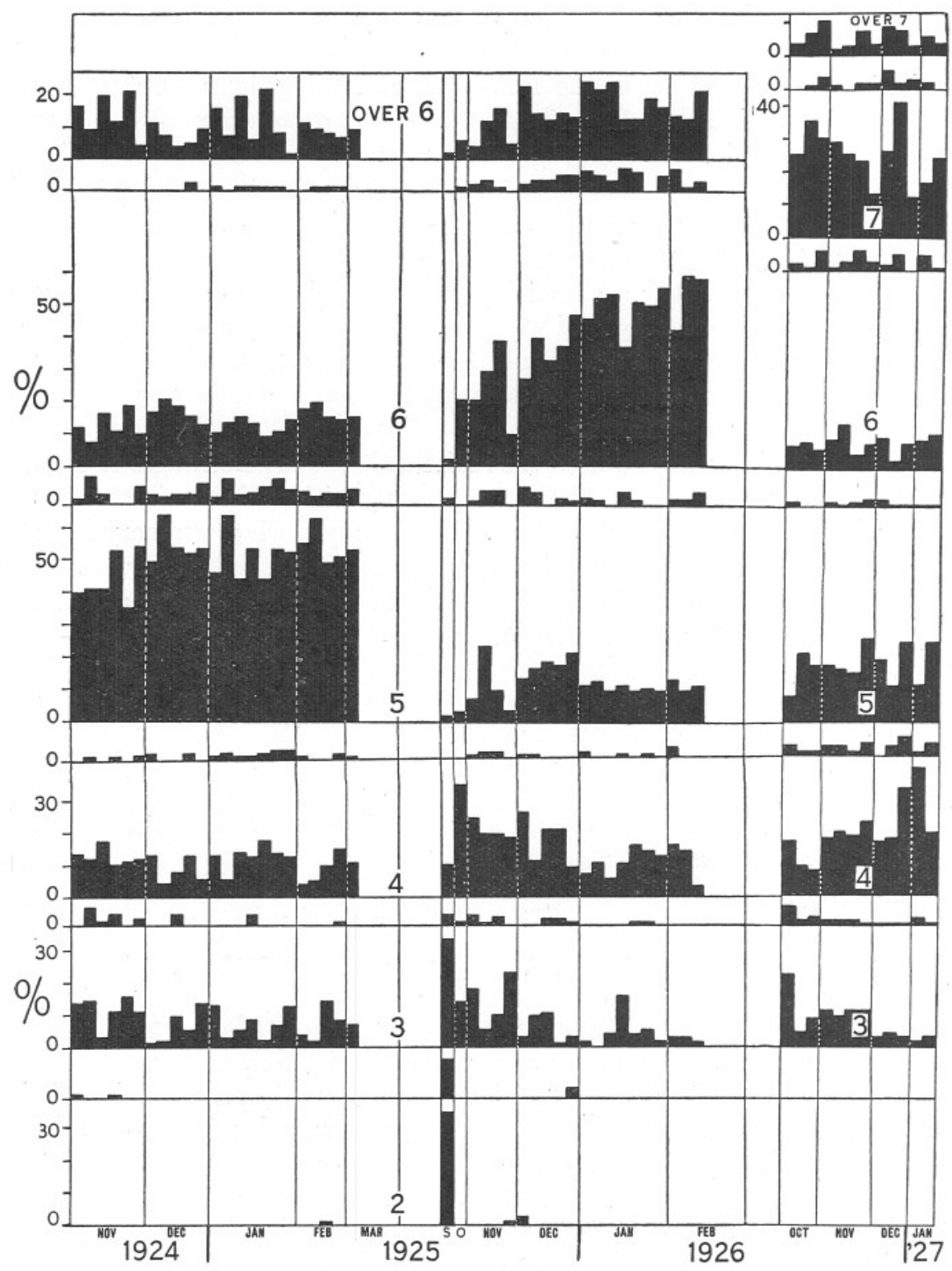

Fig. 3.-Age composition of samples of Plymouth Herrings.

Sample percentages are shown as small vertical blocks. The age-classes are as follows :

$$
\begin{aligned}
& 2 \text {. } \quad . \quad \text { 2-zoned 2-ringed. } \\
& 4 \div \quad \text {. } \quad \text { 4-zoned 4-ringed. } \\
& 5 \div \quad: \quad \text { 5-zoned 5-ringed. } \\
& 6 \text {. . . 6-zoned 6-ringed. } \\
& 7 \text {. } 7 \text {-zoned } 7 \text {-ringed. }
\end{aligned}
$$

The "interval" classes are obviously 2 or 3,3 or 4,4 or 5 , etc. 


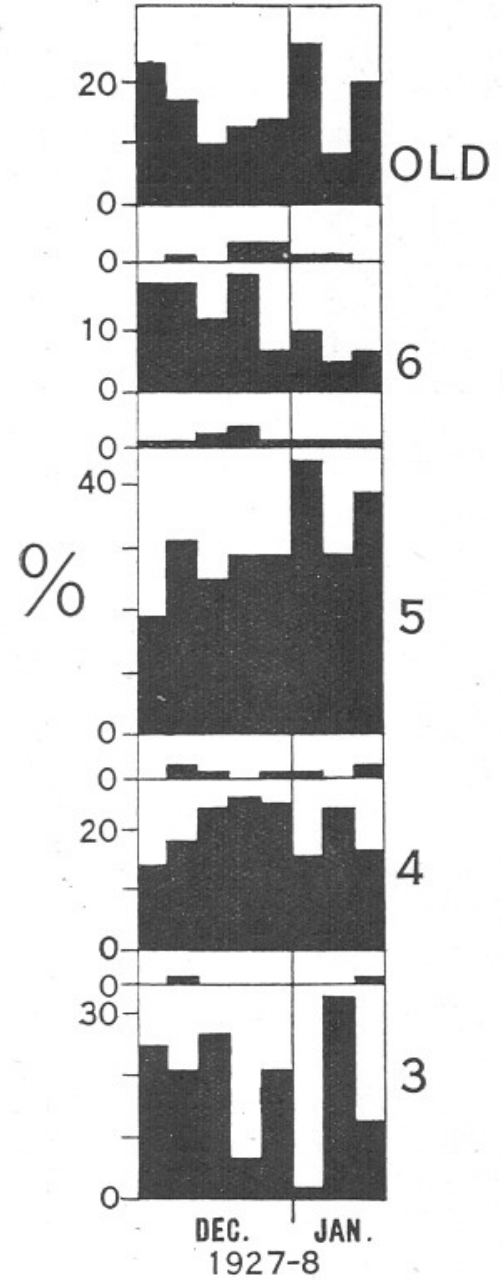

FIg. 4.-Age composition of samples of Plymouth Herrings landed during season 1927-28.

Figure constructed in same way as Fig. 3. The age-class "oLD" includes all fishes definitely older than 6-zoned 6-rings.

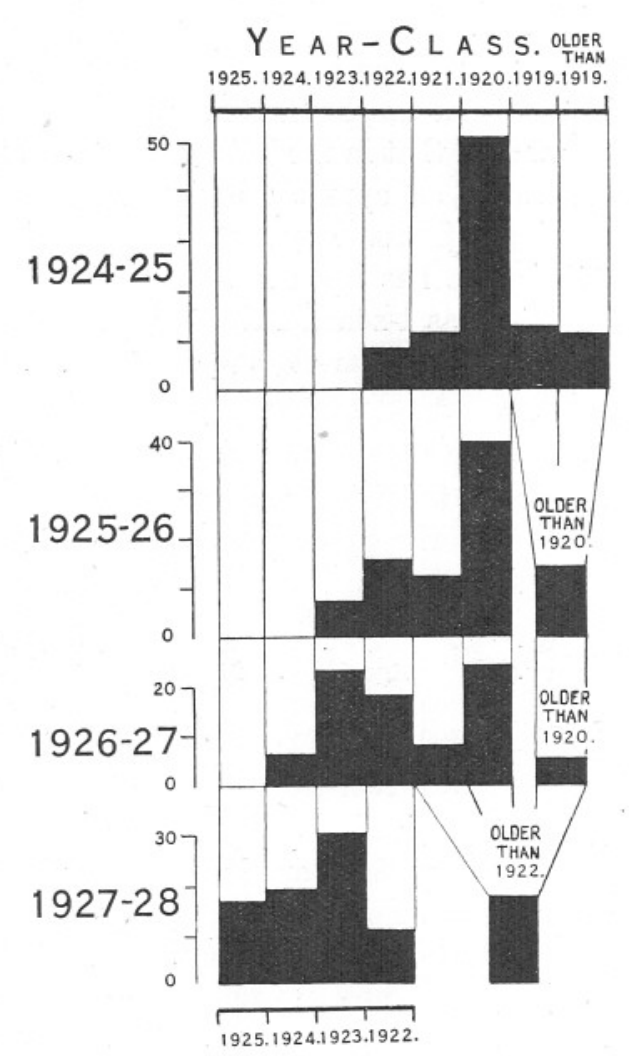

FIG. 5.-Summary of age composition during four consecutive seasons at Plymouth. The average seasonal percentage of each year-class is shown as a small vertical block. 
more than $50 \%$ of many samples ; as 6-zoned 6-ringed fishes in 1925-26 they again greatly outnumbered those of any other year-class, while as 7-zoned 7-ringed individuals in 1926-27 they were still a leading element although not so heavily represented as in previous years. But now, in 1927-28, as 8-zoned 8-ringed fishes they no longer form a dominant constituent of the samples, having been replaced by the members of younger year-classes. It is, naturally, a little disappointing that the available data do not go sufficiently far back actually to cover the whole period throughout which this successful year-class 1920 had formed part of the Plymouth catches. Judging from recent experience, it seems extremely unlikely that more than an occasional well-grown individual of this class would have been caught in 1921-22 as a 2-zoned 2-ringed fish. It is possible, however, that in the following season of 1922-23, the catches would have included an appreciable percentage of the 1920 year-class as 3-zoned 3 -ringed fishes. Furthermore, when as a result of a further year's growth their size has become well within catchable range, the percentage in 1923-24 as 4-zoned 4-ringed individuals might easily have exceeded that of any other year-class represented.

\section{Length for Age.}

In the following table the average length and individual variation for fishes of the year-classes represented during the season 1927-28 are given :-

\begin{tabular}{|c|c|c|c|c|c|c|c|c|c|c|c|c|c|}
\hline Year- & & No. & of fi: & es & eac & 1 of & & ngt & -gro & & & Total & $\begin{array}{l}\text { Average } \\
\text { length. }\end{array}$ \\
\hline class. & Age. & 21 & 22 & 23 & 24 & 25 & 26 & 27 & 28 & 29 & 30 & No. & cm. \\
\hline 1925 & 3-zoned 3-ringed & 4 & 18 & 57 & 71 & 34 & 4 & 1 & 1 & - & - & 190 & $24 \cdot 2$ \\
\hline 1924 & 4-zoned 4-ringed & - & 2 & 26 & 49 & 66 & 32 & 9 & 3 & 1 & 1 & 189 & $25 \cdot 3$ \\
\hline 1923 & 5-zoned 5-ringed & - & - & 2 & 25 & 120 & 105 & 44 & 5 & - & - & 301 & $26 \cdot 1$ \\
\hline 1922 & 6-zoned 6-ringed & - & - & - & 7 & 27 & 31 & 31 & 8 & 5 & - & 109 & $26 \cdot 7$ \\
\hline
\end{tabular}

These averages are lower than the corresponding ones for previous seasons (cf. Ford, 2, p. 293), particularly those of the 3-zoned 3-ringed and 6-zoned 6-ringed fishes. The fact that fishing during 1927-28 was conducted almost entirely on the more easterly grounds may account for this (vide Ford, 2, p. 287).

\section{Predictions of Future Fisheries.}

No one with any practical experience of the annual fluctuations to which the herring fisheries are subject, will be likely to underestimate the difficulties which have to be overcome before there can be any hope of giving reliable forecasts of future fisheries. In the pages which follow an attempt has been made to indicate how the results of the investigations during the past few seasons may be brought to bear directly upon this 
practical question. In the face of so formidable a problem, any worker might reasonably hesitate to advance suggestions after such a short period of study; it should, therefore, in fairness to the present writer, be clearly recognised that the attempted forecasts are given primarily as illustrations of the way in which the limited data may prove helpful, and, secondarily, as trial predictions which can ultimately be substantiated or disproved. Even if such forecasts do eventually prove poor, they should not necessarily be regarded as a condemnation of the whole work ; the discrepancies between forecast and reality ought rather to be examined most carefully in an endeavour to discover why they have arisen.

If we examine the data of landings by steamers over a period of years at Plymouth we are at once impressed by three facts:-

1. The average weight per landing varies greatly from one season to the next.

2. In some years the heaviest landings are made in December, whereas in others, in January.

3. Fishing operations are adversely influenced by bad weather conditions.

Of these three facts, the present work can only deal with the first two ; the influence of meteorological conditions is outside its scope, important as it may be. We have thus to discuss how the systematic study of the fishes landed during the past four seasons, and of a set of temperature records in the Plymouth area over the same period, can help us to predict the yield of a future fishery, as well as the "earliness" or "lateness " of the fishery in that season.

We have already seen that the 1920 year-class of fish formed a marked percentage of the landings in recent years. Let us, therefore, first notice the state of the fishery during those seasons when this year-class was represented in the landings. In the following table, the values of the average weight per landing by steamers are shown against the corresponding age and percentage of fishes of the 1920 year-class :-

\begin{tabular}{|c|c|c|c|c|}
\hline \multirow[b]{2}{*}{$\begin{array}{c}\text { Season } \\
\text { (Nov.-Jan.). }\end{array}$} & \multicolumn{3}{|c|}{1920 Year-class. } & \multirow{2}{*}{$\begin{array}{c}\text { Average Weight } \\
\text { per Landing } \\
\text { by Steamers. } \\
\text { cwt. }\end{array}$} \\
\hline & Zones. & Rings. & Percentage. & \\
\hline $1921-22$ & 2 & 2 & Practically unrepresented & $13 \cdot 8$ \\
\hline $1922-23$ & 3 & 3 & No data available & $25 \cdot 8$ \\
\hline $1923-24$ & 4 & 4 & No data available & $37 \cdot 8$ \\
\hline $1924-25$ & 5 & 5 & $50 \cdot 5$ & $40 \cdot 0$ \\
\hline $1925-26$ & 6 & 6 & $39 \cdot 6$ & $23 \cdot 0$ \\
\hline $1926-27$ & 7 & 7 & $24 \cdot 2$ & $16 \cdot 0$ \\
\hline $1927-28$ & 8 & 8 & $<10$ & $46 \cdot 6$ \\
\hline
\end{tabular}


We see that the average weight per landing rose each season from 1921-22 to 1924-25, but then fell away for two seasons in succession. During the same period the percentage of the 1920 year-class rose and fell in a corresponding manner. It is not unreasonable to argue that this is no mere coincidence and that the high average landings during 1923-24 and 1924-25 were the result of the maximum representation of a highly. successful year-class 1920. From this observation we could reasonably contend that had we in 1922-23 appreciated the coming importance of this year-class we could have predicted the good catches in 1924-25 and $1925-26$.

Clearly, then, as an initial step towards forecasting, we must examine our data on age composition, in order to get as much information as possible concerning the various year-classes represented.

\section{Age Composition of Samples during the four Seasons from 1924-25 to $1927-28$.}

In the following table, and in Fig. 5 on page 11, the average age composition for each of the four seasons 1924-25 to $1927-28$ is given. The seasonal averages are in each case the mean of all the sample percentages of that season, and they are tabulated according to the year-class :-

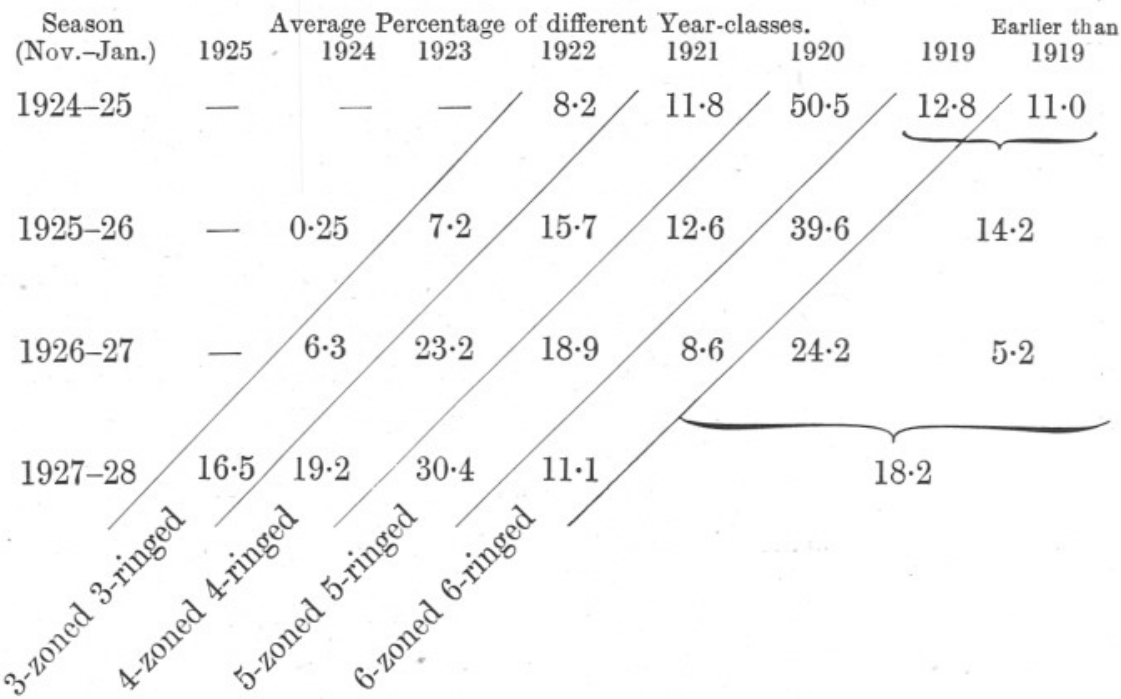

Before proceeding to examine the actual data given in the above table, it will be helpful to point out the three leading ways in which the data may be read :- 
1. By reading along a horizontal line we obtain the percentage of each year-class during the same season.

2. By reading down a vertical column we learn how the percentage of a given year-class changes from one season to the next.

3. By reading across the diagonal rows we learn the percentage of fishes in each season having a given number of zones and rings.

Turning now to the data themselves, we see, in the first place, that a year-class usually makes its initial appearance in the samples when 3-zoned 3-ringed. The 1924 year-class was an exception, but even then only an occasional 2-zoned 2-ringed fish occurred in 1925-26. Bearing in mind the relatively small size of fishes when 3-zoned 3-ringed, it is probable that as yet only the bigger representatives are caught, the smaller ones avoiding capture by passing through the mesh of the net.

In the second place, the percentage of a year-class tends to rise until its members have become 5-zoned 5-ringed. For example, in 1925-26, the percentage of year-class 1923, then 3-zoned 3-ringed, was $7 \cdot 2 \%$; in the following season, when the fishes were 4-zoned 4-ringed, the percentage rose to $23.2 \%$; in $1927-28$, when the fishes had become 5 -zoned 5-ringed, the percentage had again risen to $30.4 \%$. Year-classes 1921, 1922, and 1924 show a similar tendency (see Fig. 5 on p. 11).

Thirdly, the percentage of a year-class tends to decline when its members have passed the age of 5-zones 5-rings. Thus, in 1924-25, the percentage of year-class 1920 was $50.5 \%$, the fishes being 5-zoned 5-ringed; in 1925-26 the percentage of the same year-class, now 6-zoned 6-ringed, had dropped to $39 \cdot 6 \%$; in 1926-27, when the fishes were 7-zoned 7-ringed, the percentage had dropped still farther to the low level of $24 \cdot 2 \%$; in 1927-28 the percentage of year-class 1920 had become so reduced that by including with it the percentages of all older year-classes, as well as that of year-class 1921, the aggregate was only $18 \cdot 2 \%$. The percentages of year-classes 1919, 1921, and 1922 also showed a decline after the age of 5-zones 5-rings was reached (see Fig. 5, p. 11).

Let us now return to the 1927-28 data. Five distinct age-groups are concerned, viz. : the four year-classes 1925, 1924, 1923, and 1922, and the composite group which includes all fishes of the years prior to 1922 . Arguing on the indications arrived at above, we can make some progress if asked to predict what will happen during the next few seasons. We will consider each age-group in turn :-

\section{(A) Year-class 1925.}

Members of this class, as 3-zoned 3-ringed individuals, formed 16.5\% during the season 1927-28. It will be observed that this percentage was 
considerably greater than that for similar-aged fish in any of the preceding seasons, indicating that the year-class 1925 is likely to prove a highly successful one. We should expect that during the season 1928-29, when the fish will be 4-zoned 4-ringed, the percentage will prove appreciably higher-perhaps from two to three times that shown in 1927-28. In the following season of 1929-30, when the members of this same year-class will be 5-zoned 5-ringed, we may look for a percentage greater even than that of 1928-29-perhaps amounting to $50 \%$ of the total sample. In the next season (1930-31), when an age of 6-zones 6-rings will be reached, we may expect to witness the beginning of a decline in importance, which decline will in subsequent seasons become more and more pronounced.

(B) Year-class 1924.

Members of this class, as 4-zoned 4-ringed individuals, formed 19.2\% during the season 1927-28, a value which compared fairly favourably with that for fishes of corresponding age in previous seasons. We should expect in 1928-29 a somewhat increased percentage, say approaching $25 \%$. In the following season (1929-30) the first evidence of a falling-off in numbers would be anticipated, for the fishes will then have become 6-zoned 6 -ringed. In the next season (1930-31) the percentage will probably have become reduced to an amount hardly large enough to be considered an important element of the catches.

(C) Year-class 1923.

Fishes of this class, as 5-zoned 5-ringed individuals, comprised 30.4\% during the season 1927-28. This percentage must be regarded as the highest likely to be reached by this year-class. The first signs of depletion are to be looked for in 1928-29, although the percentage then reached should still form an appreciable constituent of the samples. In 1929-30, a further reduction would be expected, while in 1930-31 this year-class will probably cease to be more than nominally represented.

(D) Year-class 1922 .

This year-class had already passed its zenith in 1927-28, so that in 1928-29 it cannot be expected to enter much into the landings.

(E) Year-classes of 1921 and earlier years.

As with year-class 1922, these year-classes had in 1927-28 already passed out of the stage when they could be considered likely to continue as important constituents of the landings.

If we take as a criterion of relative importance a percentage of $10 \%$, we can, from the observations made under $(\mathrm{A})$ to $(\mathrm{E})$, suggest the future 
season during which each of the year-classes represented in 1927-28 will cease to be an important element of the samples :-

\begin{tabular}{|c|c|c|c|c|}
\hline Year-classes of 1 & 1 and & er years & During seaso & n 1928-29 \\
\hline Year-class 1922 & . & . . & ,, , , & 1928-29 \\
\hline Year-class 1923 & . & . & , & $1929-30$ or $1930-31$ \\
\hline Year-class 1924 & . & . & , & $1930-31$ \\
\hline Year-class 1925 & . & . & , & $1931-32$ or $1932-33$ \\
\hline
\end{tabular}

Thus by 1932-33, i.e. five seasons hence, practically the whole of the stock represented in this season of 1927-28 will have been replaced by new stock.

It is important to realise, however, that no consideration of the sample data for any given season can yield the slightest information concerning the proportion of new year-classes which will appear in the future. But, by watching the actual percentage of 3-zoned 3-ringed fishes in each season, we can obtain advanced warning of the part likely to be played by a newly arrived year-class. If the percentage of 3-zoned 3-ringed fishes is unusually high, we may expect fishes of that year-class to become a leading constituent of the landings during the next two seasons at least ; if, on the other hand, 3-zoned 3-ringed fishes are relatively few, we shall not expect great subsequent yield from that year-class.

\section{Age Composition in Relation to Density of Landings.}

In the preceding section we endeavoured to predict the proportions of the different year-classes in samples of future seasons. We have next to discuss the probable effects of these changes in proportion on the density of commercial landings. At this stage it is necessary for us to recall that in our age-estimates we are dealing with percentages and not absolute values. Thus to determine the numerical abundance of fishes of a given year-class in a particular season, we must interpret our age-percentages in terms of the absolute density of fish-in our case, the average weight per landing by the steamers. With these two sets of data available, let us try first to sum up the situation during the season 1927-28, when the average weight per landing rose to a new high level. (See table on p. 13.) We can safely conclude that the good landings in that season were not due to the year-classes 1920 and 1921, for the former had at that time become seriously depleted, while the latter had been poorly represented during the two previous seasons when most would be expected from it. Evidence seems in favour of the view also, that year-class 1922 was of minor importance; had it been one of appreciable success we should not have expected the average weight per landing in 1926-27, when fishes of this class were 5-zoned 5-ringed, to have fallen so low as $16 \mathrm{cwt}$. Our 
attention is thus attracted particularly to year-classes 1923, 1924, and 1925. Of these three, year-class 1923 had already given promise in 1926-27 of being a more important one than its immediate predecessors of 1921 and 1922, and the possibility of an increase in its significance in 1927-28 was suggested in an earlier Report. (Ford, 2, p. 291.) Here again, however, the low average landing in 1926-27 does not support the view that year-class 1923 was an outstanding success like that of 1920, although it must be regarded as a considerable improvement on year-classes 1922 and 1921 on account of its importance during 1927-28.

Turning next to year-class 1924, we note that its members, as 4-zoned 4-ringed fishes during the season 1927-28, contributed $19 \cdot 2 \%$ towards the high average landing of $46 \cdot 6 \mathrm{cwt}$. We must therefore regard this yearclass as of at least average importance, and expect it to yield a satisfactory quota to catches of the immediate future. The percentage of 6.3 in 1926-27 when the fishes of the class were 3-zoned 3-ringed, however, did not arouse unusually high expectations.

The third of the classes to be considered is that of 1925 which appeared for the first time in appreciable numbers in 1927-28. Here we have very real hopes of a new highly successful group which in the first year of appearance constitutes a percentage of $16.5 \%$ of a high seasonal yield.

We are now in a position to attempt a forecast for the forthcoming season of 1928-29. On the indications considered above, we should expect the following :-

1. A decline in the abundance of the fairly rich year-class 1923 .

2. An increase in the fairly rich year-class 1924 .

3. An increase in the rich year-class 1925 .

We should, under the circumstances noted, expect that the total increase resulting from (2) and (3) would more than counterbalance the decrease due to (1). That is to say, so far as the old stock is concerned, there should be a better available supply of fish in 1928-29 than in 1927-28. Furthermore, an additional new element, the 1926 year-class, should appear as 3-zoned 3-ringed fishes, but no forecast can, at present, be offered concerning the extent to which this may be expected. Altogether, then, so far as the available supply of fish is concerned, the prospects for the season 1928-29 would appear favourable.

\section{Early and Late Seasons.}

It is well known that at Plymouth, as elsewhere, the season is sometimes early, sometimes late. Any form of observation which would give a reliable indication of the time at which good fishing might be expected in an impending season, would, therefore, be of material practical utility. 
We know that, at Plymouth, the shoals which arrive in the winter are concentrating for spawning. It is reasonable to think that such a physical factor as the temperature of the sea will influence the development and ultimate maturation of the roes and milts, and, in consequence, will have its effect on the time at which the fishes approach the spawninggrounds. Since the year 1921, regular observations of temperature at certain hydrographical stations in the Plymouth area have been made by Dr. Atkins and Mr. Harvey of the Laboratory Staff. We may safely use the data on temperature at a depth of 10 metres at Station $\mathrm{E}_{1}$

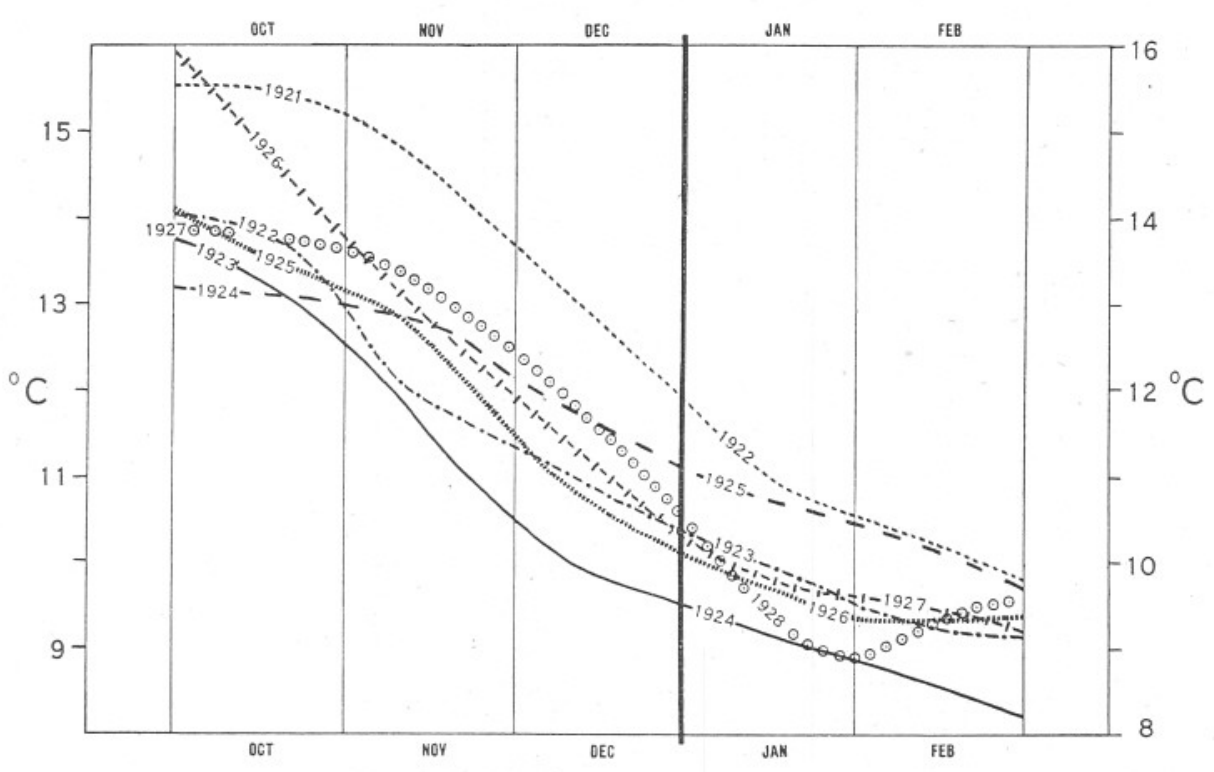

FIG. 6.-Temperatures at 10 metres depth at Hydrographical Station $\mathrm{E}_{1}$.

(ca. 10 miles S.W. of the Eddystone) as an approximation to the temperature conditions prevailing over the Plymouth herring fishing-grounds (vide Ford, 2, p. 287). In Fig. 6 the temperatures during the winter months are expressed in the form of smoothed curves drawn to fit the data.

From the curves in Fig. 6, the following average values for the seven seasons have been determined :-

$\begin{array}{ccccc}\text { Date. } & \text { Nov. 1st. } & \text { Dec. 1st, } & \text { Jan. Ist. } & \text { Feb. Ist. } \\ \text { Average temp. }\left({ }^{\circ} \mathrm{C}\right) & 13.5 & 11.9 & 10.5 & 9.6\end{array}$

Comparing the records for individual seasons with the above averages, we see at once that during 1921-22 the temperatures were much above the normal throughout the months of November, December, and January, 
whereas during 1923-24 they were consistently below the normal. It is of immediate interest to examine the monthly landings of herrings during these two markedly abnormal years. For this purpose, the landings by motor-drifters are the more convenient, for these vessels are at work during November, whereas the steamers rarely arrive in numbers until December. Here are the data of landings by motor-drifters during the two seasons 1921-22 and 1923-24 :-

\begin{tabular}{cccc} 
& \multicolumn{2}{c}{ Total Weight of Fish Landed by Motor-Drifters. (Cwt.) } \\
Season. & November. & December. & January. \\
$1921-22$ & 293 & 2,103 & 4,325 \\
$1923-24$ & 23,492 & 23,840 & 17,325
\end{tabular}

The contrast between these two sets of data is striking. In the first place it is seen that the total landed during November was almost negligible in 1921-22 but of real importance in 1923-24. This observation becomes of additional interest when it is realised that in the month of November, during each of the remaining five of the series of seven seasons, the total weight landed never once exceeded $9000 \mathrm{cwt}$., nor was it less than $4000 \mathrm{cwt}$. In the second place it is seen that in 1921-22 the greatest quantity of fish was landed as late as January, whereas in 1923-24 the best catches were taken in November and December.

There appears to be no evidence that these two facts can be entirely explained by differences in intensity of fishing due to the number of vessels working in the two seasons, or to varying weather conditions. Turning to the temperature records, therefore, it is interesting to notice that the temperature range during January, 1922, corresponded with that prevailing during the greater part of November, 1923. From this we may well suppose that catches are likely to be considerably better in waters below $12^{\circ} \mathrm{C}$. than in waters above $12^{\circ} \mathrm{C}$. in temperature.

Referring once more to Fig. 6 , we see that the temperatures prevailing during the season 1924-25 are interesting in that the curve, like those for 1921-22 and 1923-24, is a departure from the normal, although of a different character. The water during late December and the whole of January was appreciably warmer than usual. Thus on January 1st, 1924, the temperature was about $11 \cdot 1^{\circ} \mathrm{C}$. compared with the normal of $10 \cdot 5^{\circ} \mathrm{C}$., and on February 1st it was still as high as $10 \cdot 5^{\circ} \mathrm{C}$., compared with the normal of $9 \cdot 6^{\circ} \mathrm{C}$. Comparing the average weight of fish per landing by the steamers during December, 1924, and January, 1925, we find that the average was higher during the latter month (Dec., 1924=20.3 cwt., Jan., $1925=50 \cdot 7 \mathrm{cwt})$. . That is to say, superior catches coincided with a temperature lower than about $11 \cdot 1^{\circ} \mathrm{C}$.

From these observations concerning three seasons abnormal so far as temperature is concerned we may, therefore, draw up an experimental 
progress report regarding the yield of the fishery with respect to the temperature of the sea :-

\begin{tabular}{|c|c|c|c|c|c|c|}
\hline $\begin{array}{l}\text { Temperature } \\
{ }^{\circ} \mathrm{C} \text {. }\end{array}$ & & & & & & Expected Yield. \\
\hline Above 13 & . & . & . & . & . & poor. \\
\hline $13-12$. & . & . & . & . & . & . improving. \\
\hline $12-11$. & . & . & . & . & . & . fair. \\
\hline Below 11 & . & . & . & . & . & . good. \\
\hline
\end{tabular}

Assuming that this report is sound, we can, from the temperatures representing the average conditions for the seven seasons (given on p. 19),

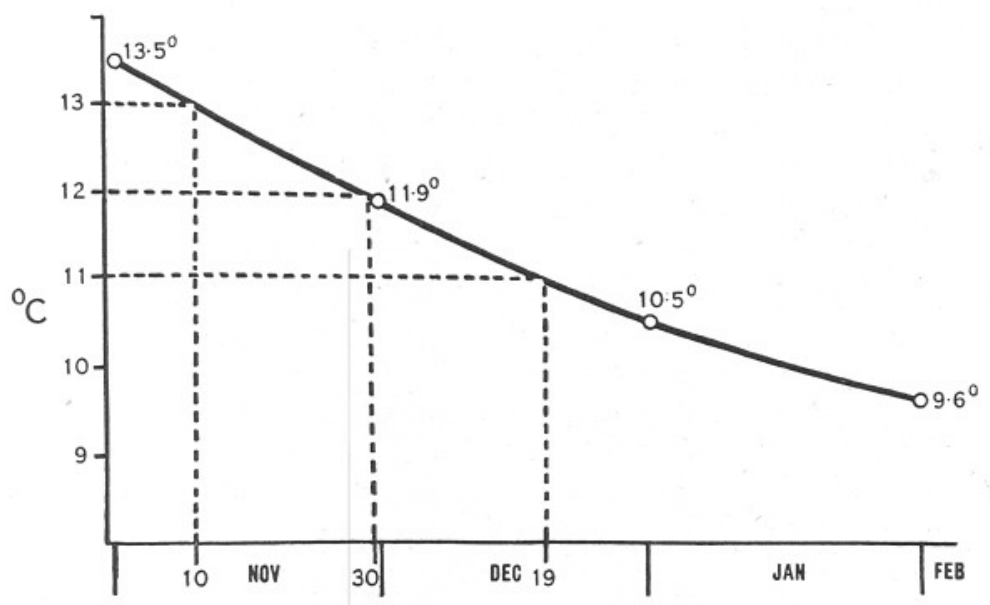

FIG. 7.-Average temperatures at 10 metres depth at Hydrographical Station $\mathrm{E}_{1}$, based on the seven seasons' data given in Fig. 6. The dates at which $13^{\circ} \mathrm{C}$., $12^{\circ} \mathrm{C}$. and $11^{\circ} \mathrm{C}$. are reached are indicated.

deduce a hypothetical "normal" time table of fishing. In Fig. 7, a smooth curve has been drawn to pass through the calculated average temperatures, from which we can determine the dates at which the criterion temperatures are reached :-
$13^{\circ} \mathrm{C}$.
$12^{\circ} \mathrm{C}$.
$11^{\circ} \mathrm{C}$.

November 10th. November 30th. December 19th.

We should therefore expect fishing normally to be poor until November 10th; improving from November 11th to November 30th; fair from December 1st to December 19th, and to become really satisfactory on December 20th.

\section{Future Investigations.}

In the above sections an attempt has been made to demonstrate the application of the study of the age of herrings, and the temperature conditions on the fishing-grounds to the question of the prediction of 
future fisheries. It has been shown that advanced knowledge of the probable abundance of fish in a future season can be obtained by the study of the age of fishes in earlier years in conjunction with statistical data on market landings. Clearly, then, similar work should be carried out in the seasons which are to come in order to verify or improve upon the conclusions so far reached. With regard to the prediction of a " time table" of fishing, there is good reason to advocate the observation of temperature over the fishing-grounds at short intervals, from, say, the beginning of November onwards, so that more precise data may be obtained concerning the coincidence of fishing results with water temperature.

It is hardly necessary to point out that there are factors likely seriously to influence local fishing which in these pages have not been taken into account at all, such as variations in strength and direction of winds; the changing tides, or the phases of the moon. While we know with certainty that gales frequently prevent the smaller vessels from leaving harbour, and that wind and tide materially affect actual fishing operations, we do not, as yet, possess much knowledge concerning the effect of such factors on the fish themselves. Conceivably, it is possible that fish may be present in the vicinity in good quantity, although few can be caught. For instance, do fish react to a period of calm sea over the time of " dead " tides?-Do they, as one experienced skipper suggests, keep to the bottom owing to the resulting clearness of the water ? If a wind now arises, will it "stir the fish" and so cause better fishing? Is an offshore (northeasterly) wind bad for fishing? Does the light of a full moon induce the fish to take to the deeper layers? Such questions as these remain to be solved, but the solutions will be hard to accomplish on account of the practical difficulties in observation.

There is also the question of the particular local grounds on which fish are plentiful in one year, or during one part of the season, and not in another. Why, for example, are fish located comparatively far up Channel towards Brixham, in one season, and away down Channel to the westward of Plymouth in another ? Can these variations be accounted for and thus predicted? It is suggested that the study of growth from scalemeasurements, and the comparisons between fishes from different parts of the Channel and south-western district will lead to a fuller knowledge of the origin and movements of the herring shoals visiting Plymouth, and that this information should ultimately indicate the particular local grounds likely to be frequented by shoals of known character. This accomplished, the further work of anticipating the future stock for these particular grounds can be undertaken. In this connection the study of fishes landed at Brighton, Brixham, Mevagissey, Newlyn, Padstow, and Milford, during the past few years has provided data of immediate value. 
Finally, there remains the study of the circumstances which control the survival of the yearly broods of young herrings resulting from the spawning of the visiting shoals, for until we are fully acquainted with these facts, we cannot foretell what amount of new stock will arrive in a future season. This necessitates the detailed investigation of the history of the fish from the egg until the age of three years is reached, and, also, of the physical and other conditions which determine the number of fishes which will survive to enter the adult shoals. It is only in this way that we can arrive at an explanation of the amazing success of some year-classes and the complete failure of others; while, as has already been shown, knowledge in advance of outstanding year-classes is also knowledge in advance of fishing prospects.

\section{LITERATURE CITED.}

1. Ford, E. "Herring Investigations at Plymouth. I. Methods of Collection and Treatment of Data." Journ. Mar. Biol. Assoc., Vol. XV, No. 1, 1928.

2. ForD, E. " Herring Investigations at Plymouth. III. The Plymouth Winter Fishery during the seasons 1924-25, 1925-26, and 1926-27." Journ. Mar. Biol. Assoc., Vol. XV, No. 1, 1928.

3. Hodgson, W. C. "Preliminary Note on Experiments concerning the Selective Action of Drift Nets." Journal du Conseil., Vol. II, No. 3, 1927.

4. Wallace, W. "First Report on Young Herring in the Southern North Sea and English Channel-Part I." Min. Agric. Fish., Fishery Invest., Ser. II, Vol. VII, No. 4, 1924.

\section{TABLE I.}

\section{Length Distribution (cm.).}

\begin{tabular}{|c|c|c|c|c|c|c|c|}
\hline Sample. & $\begin{array}{l}\text { Date. } \\
1927\end{array}$ & $\begin{array}{l}\text { Total } \\
\text { No. of } \\
\text { Fishes }\end{array}$ & $\begin{array}{l}\text { Lower } \\
\text { Limit. }\end{array}$ & $\begin{array}{c}\text { Lower } \\
\text { Quartile } \\
Q_{1}\end{array}$ & $\begin{array}{c}\text { Median } \\
\mathrm{Q}_{2}\end{array}$ & $\begin{array}{c}\text { Upper } \\
\text { Quartile } \\
Q_{3}\end{array}$ & $\begin{array}{l}\text { Upper } \\
\text { Limit. }\end{array}$ \\
\hline 1 & Oct. 17 & 100 & $23 \cdot 5$ & $24 \cdot 6$ & $25 \cdot 4$ & $26 \cdot 2$ & $28 \cdot 5$ \\
\hline 2 & Nov. 10 & 110 & $24 \cdot 5$ & $26 \cdot 0$ & $26 \cdot 6$ & $27 \cdot 5$ & $30 \cdot 5$ \\
\hline 3 & Dec. 2 & 110 & $21 \cdot 5$ & $25 \cdot 0$ & $26 \cdot 0$ & $27 \cdot 1$ & $30 \cdot 5$ \\
\hline 4 & Dec. 8 & 110 & $23 \cdot 5$ & $24 \cdot 9$ & $25 \cdot 9$ & $27 \cdot 4$ & $29 \cdot 5$ \\
\hline 5 & Dec. 14 & 100 & $22 \cdot 5$ & $24 \cdot 4$ & $25 \cdot 6$ & $26 \cdot 6$ & $29 \cdot 5$ \\
\hline 6 & Dec. 21 & 100 & $22 \cdot 5$ & $24 \cdot 1$ & $25 \cdot 2$ & $26 \cdot 5$ & $29 \cdot 5$ \\
\hline 7 & Dec. 30 & 100 & $22 \cdot 5$ & $24 \cdot 4$ & $25 \cdot 3$ & $26 \cdot 6$ & $30 \cdot 5$ \\
\hline & 1928 & & $24 \cdot 5$ & 25.9 & $26 \cdot 7$ & $27 \cdot 6$ & $29 \cdot 5$ \\
\hline $\begin{array}{l}8 \\
9\end{array}$ & $\begin{array}{l}\text { Jan. } 2 \\
\text { Jan. } 17\end{array}$ & $\begin{array}{l}100 \\
100\end{array}$ & $\begin{array}{l}24 \cdot 5 \\
21 \cdot 5\end{array}$ & $\begin{array}{l}20.9 \\
23 \cdot 5\end{array}$ & $\begin{array}{l}26 \cdot 7 \\
24 \cdot 7\end{array}$ & $26 \cdot 1$ & $\begin{array}{l}29 \cdot 5 \\
30 \cdot 5\end{array}$ \\
\hline 10 & Jan. 28 & 100 & $22 \cdot 5$ & $24 \cdot 1$ & $26 \cdot 0$ & $27 \cdot 4$ & 29.5 \\
\hline 11 & Mar. 3 & 100 & $22 \cdot 5$ & $25 \cdot 2$ & $26 \cdot 4$ & $28 \cdot 1$ & $31 \cdot 5$ \\
\hline
\end{tabular}




\section{TABLE II.}

$\begin{array}{ll}\text { Percentage Age Composition. } & \text { Total } \\ \text { No. of }\end{array}$

Date. $\quad$ Older Fish in

Sample. $\quad 1927 \quad 2 \quad 3 \quad 3-4 \quad 4 \quad 4-5 \quad 5 \quad 5-6 \quad 6 \quad 6$-old. than $6 \quad$ ? Sample.

$1 \quad$ Oct. $17441-14-23 \quad 1 \quad 8 \quad-\quad 9 \quad-100$

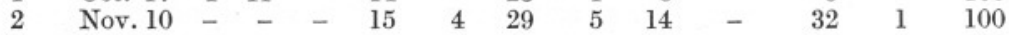

3 Dec. $2-25-14-19 \quad 118-100$

4 Dec. 8 - $\begin{array}{llllllllllll} & 21 & 1 & 18 & 2 & 31 & 1 & 8 & 1 & 17 & - & 100\end{array}$

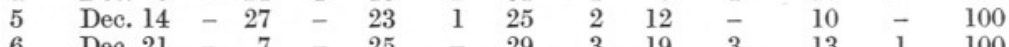

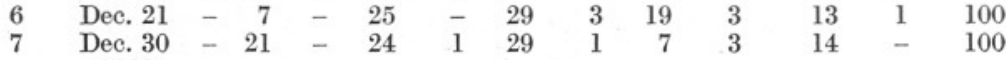

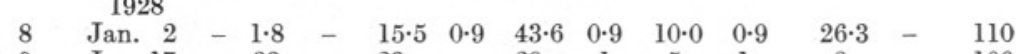

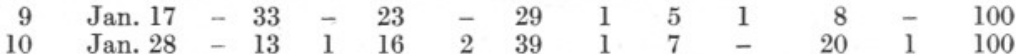

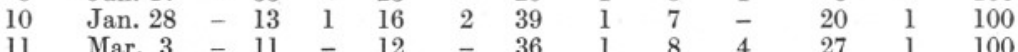

